\title{
PENGARUH KEPEMIMPINAN TRANSFORMASIONAL DAN KEPUASAN KERJA TERHADAP MOTIVASI BERPRESTASI PEGAWAI SEKRETARIAT BADAN PENGEMBANGAN SUMBER DAYA MANUSIA PERHUBUNGAN
}

\author{
Widiah Nur Wahyuni ${ }^{1}$
}

\begin{abstract}
The objective of this research is to obtain information about the effect of transformational leadership and job satisfaction on employee achievement motivation of Badan Pengembangan Sumber Daya Manusia Perhubungan. It was quantitative research with survey method in Badan Pengembangan Sumber Daya Manusia Perhubungan. The research was conducted to all employees of Badan Pengembangan Sumber Daya Manusia Perhubungan by using a survey method with path analysis applied in testing hypothesis. The number 89 employees as sample was selected by using Slovin formula. The research conlude: (1) There is a direct positive effect of transformational leadership on achievement motivation. (2) There is a direct positive effect of job satisfaction on achievement motivation. (3) There is a direct positive of transformational leadership on job satisfaction.
\end{abstract}

Keywords: transformational leadership, job satisfaction, achievement motivation.

\section{PENDAHULUAN}

Sebagai organisasi yang melaksanakan tugas pelayanan administratif, Sekretariat Badan Pengembangan Sumber Daya Manusia Perhubungan menyelenggarakan salah satu fungsinya yaitu pembinaan administrasi kepegawaian Badan Pengembangan Sumber Daya Manusia Perhubungan. Untuk itu, pegawai mempunyai peranan penting dalam pelaksanaan tugas pokok dan fungsi yang dapat mendukung pencapaian tujuan organisasi.

Keberhasilan sebuah organisasi dalam pencapaian tujuan ditentukan oleh pengelolaan sumber daya manusia yang dimiliki karena dalam proses pencapaian tujuan tersebut seringkali menjadi hambatan. Sumber daya manusia merupakan hal yang sangat penting adanya dalam kelangsungan dan kemajuan sebuah organisasi. Selain itu, kepemimpinan juga merupakan faktor terpenting yang dapat menunjang keberhasilan suatu organisasi dengan menumbuhkan semangat kerja dan kebersamaan untuk mencapai tujuan organisasi yang telah ditetapkan.

Pemimpin yang efektif mampu membangun motivasi staf, menentukan arah, menangani perubahan secara benar, dan menjadi katalisator yang mampu mewarnai sikap dan perilaku staf. Motivasi orang tergantung pada kekuatan motif-motif mereka. Kebanyakan seseorang memiliki sejumlah besar motif dengan berbagai kekuatan dalam program motivasi berprestasi. Motivasi berprestasi dapat menjadi suatu dorongan dalam diri seseorang untuk melakukan atau mengerjakan sesuatu kegiatan atau tugas dengan sebaik-baiknya, agar mencapai prestasi kerja (kinerja) dengan predikat terpuji.

Pemimpin dalam menjalankan kepemimpinannya menjadi salah satu kunci dalam meningkatkan motivasi berprestasi pegawai Sekretariat Badan Pengembangan Sumber Daya Manusia Perhubungan. Peningkatan motivasi berprestasi pegawai harus mendapat prioritas utama. Orang yang memiliki motivasi berprestasi cenderung lebih

\footnotetext{
${ }^{1}$ Pegawai Negeri Sipil Sekretariat Badan Pengembangan Sumber Daya Manusia Perhubungan
} 
cepat dan baik dalam menyelesaikan tugas-tugas dan berorientasi kepada prestasi. Semakin tinggi motivasi berprestasi seseorang, semakin besar ekspektasi yang mereka miliki, semakin tinggi pula pengorbanan yang mereka berikan. Seseorang dianggap mempunyai motivasi berprestasi jika dia berkeinginan untuk melakukan suatu karya yang hasilnya lebih baik daripada yang rata-rata umum bisa dicapai orang lain.

Motivasi berprestasi tidak tumbuh dengan sendirinya tetapi motivasi berprestasi tumbuh dan berkembang karena adanya lingkungan yang memungkinkan, seperti kepemimpinan dalam organisasi yang mampu mempengaruhi, memberdayakan, dan menggali potensi pegawai. Sehubungan dengan kepemimpinan, maka untuk memicu timbulnya motivasi berprestasi pegawai diperlukan hubungan kerjasama yang sinergi antara pimpinan dan pegawainya. Oleh karenanya dibutuhkan suatu gaya kepemimpinan yang bisa mendukung tugas dan tanggung jawab pemimpin. Dengan menerapkan gaya kepemimpinan yang tepat diharapkan pemimpin dapat menciptakan komunitas kepegawaian yang profesional.

Sekretariat Badan Pengembangan Sumber Daya Manusia Perhubungan di dalam melaksanakan peningkatan layanan administratif kepada seluruh satuan organisasi di lingkungan Badan Pengembangan Sumber Daya Manusia Perhubungan tidak terlepas dari masalah-masalah yang terkait dengan pegawai, salah satunya adalah motivasi berprestasi. Terkait dengan masalah motivasi berprestasi pegawai di Sekretariat Badan Pengembangan Sumber Daya Manusia Perhubungan ini, gaya kepemimpinan transformasional sangat diperlukan dalam rangka meningkatkan motivasi berprestasi pegawai sehingga dapat mewujudkan tujuan organisasi serta memberikan pelayanan administratif yang profesional.

Dalam upaya meningkatkan motivasi berprestasi membutuhkan gaya kepemimpinan yang dapat mendukung tugas pokok dan fungsi organisasi. Berdasarkan informasi yang didapat dari Kepala Bagian Kepegawaian Sekretariat Badan Pengembangan Sumber Daya Manusia Perhubungan disampaikan bahwa motivasi berprestasi pegawai Sekretariat Badan Pengembangan Sumber Daya Manusia Perhubungan belum sesuai yang diharapkan salah satu penyebabnya pegawai memerlukan figur seorang pemimpin yang dapat memberikan teladan bagi pegawainya baik dalam berkreatifitas maupun berinovasi. Dengan melihat pemimpin yang penuh dengan kreatifitas dan inovasi dapat mendorong pegawai untuk termotivasi untuk meraih prestasi. Hal lain yang dibutuhkan pegawai dalam meningkatkan motivasi untuk berprestasi yaitu dorongan lebih pada pelaksanaan tugas kantor dan pengawasan dari masing-masing atasannya.

Selain hal tersebut diatas, informasi yang peneliti himpun motivasi pegawai di Sekretariat Badan Pengembangan Sumber Daya Manusia Perhubungan masih belum memenuhi harapan yang diinginkan. Masih terdapat pegawai yang datang terlambat tidak sesuai dengan waktu yang ditentukan. Komitmen pegawai tehadap pekerjaannya masih belum nampak secara optimal. Hal ini terlihat dari sikap pegawai yang masih memilih pekerjaan yang dikerjakan. Komunikasi antar pegawai saat merencanakan penugasan pekerjaan belum terdistribusi dengan baik sehingga terdapat pegawai yang kelebihan beban kerja dan pegawai yang kurang beban kerjanya. Pegawai masih bergantung kepada atasan, kreatifitas dan inovasinya dalam pekerjaan masih belum muncul. Pengambil kebijakan belum memanfaatkan kompensasi sebagai salah satu faktor strategis yang dapat mempengaruhi motivasi.

Memperhatikan kondisi-kondisi yang telah dipaparkan diatas, peneliti memandang perlunya dikaji tentang gaya kepemimpinan transformasional dan kepuasan kerja terhadap motivasi berprestasi pegawai Sekretariat Badan 
Pengembangan Sumber Daya Manusia Perhubungan.

\section{Motivasi Berprestasi}

Motivasi merupakan proses yang dimulai dengan defisiensi fisiologis atau psikologis yang menggerakkan perilaku atau dorongan yang ditujukan untuk tujuan atau insentif. Menurut Luthans (2011:157) motivasi memiliki tiga unsur yang saling berinteraksi, yaitu "(1) need, (2) drive, (3) incentive". Need adalah kebutuhan yang tercipta saat tidak adanya keseimbangan fisiologis atau psikologis. Drive adalah dorongan fisiologikal dan psikologikal berorientasi pada tindakan dan menyediakan energi untuk mencapai insentif, sedangkan incentive adalah segala hal yang dapat mengurangi sebuah kebutuhan dan dorongan. Motivasi sebagai suatu kebutuhan dikemukakan oleh McClelland yang dikutip oleh John R. Schermerhorn, et.al, (2011:113) dibagi dalam tiga bentuk yaitu: "need for achievement, need for affiliation, and need for power". Need for achievement adalah keinginan untuk melakukan sesuatu yang lebih baik atau lebih efisien, untuk memecahkan masalah, atau untuk menguasai tugas-tugas kompleks. Need for affiliation merupakan keinginan untuk membangun dan berhubungan yang ramah secara dekat. Need for power adalah keinginan untuk mengendalikan orang lain, pengaruh perilaku mereka, atau bertanggung jawab atas lainnya. Menurut Slocum dan Hellriegel (2011:164-166) "achievement motivation model states that individuals are motivated according to the strength of their desire either to perform in terms of a standard of excellence or to succed in competitive situations. Characteristics of high achievers are they like to set their own goals, they avoid selecting extremely difficult goals, they prefer tasks that provide immediate feedback". Model motivasi berprestasi menyatakan bahwa orang termotivasi berdasarkan keinginan untuk mencapai keunggulan atau sukses dalam situasi yang memerlukan persaingan. Ciri pribadi yang memiliki motivasi berprestasi tinggi adalah berusaha unggul, mereka memilih tugas yang menantang, dan mereka lebih menyukai tugas-tugas yang menyiapkan feedback langsung.

Selanjutnya menurut Luthans dan Doh (2012:435) "achievement motivation theory holds that individuals can have a need (1) to get ahead, (2) to attain success, and to reach objectives. High achievers like situations in which they (3) take personal responsibility for finding solutions to problems, tend to be moderate risk takers, and (4) want concrete feedback on their performance". Menurut konsep ini, individu yang memiliki motivasi berprestasi berkebutuhan untuk (1) mencapai keunggulan, (2) meraih kesuksesan dan mencapai tujuan, (3) menyukai situasi yang memerlukan tanggung jawab pribadi dalam menemukan solusi untuk masalah yang timbul, cenderung untuk mengambil resiko yang tingkat kesulitannya sedang, dan (4) ingin memperoleh umpan balik secara konkrit untuk kinerja mereka. Menurut McShane dan Von Glinow (2008:141) "need for achievement Need is a learned need in which people want to (1) accomplish reasonably challenging goals, and desire (2) unambiguous feedback and recognition for their success". Kebutuhan berprestasi adalah keinginan untuk (1) menerima tugas yang menantang dan (2) ingin memperoleh feedback dengan cepat (3) serta pengakuan atas keberhasilan mereka.

Berdasarkan deskripsi konsep-konsep di atas dapat disintesiskan motivasi berprestasi adalah keinginan seseorang untuk melakukan upaya dalam rangka mencapai prestasi terbaik dengan indikator: (1) berusaha unggul, (2) keinginan menyelesaikan tugas dengan baik, (3) keinginan memperoleh umpan balik, (4) menyukai tantangan, (5) bertanggung jawab. 


\section{Kepemimpinan Transformasional}

Kepemimpinan dan organisasi merupakan dua konsep yang tidak bisa dipisahkan antara satu dengan yang lainnya. Dalam organisasi kepemimpinan sangat dibutuhkan untuk memberikan pengarahan terhadap usaha-usaha semua pekerja dalam mencapai tujuan-tujuan organisasi. Oleh karena itu, kepemimpinan sangat diperlukan bila suatu organisasi ingin sukses. Menurut Stephen P. Robbins, Timothy A. Judge (2013:402) "leadership is the ability to influence a group toward the achievement of vision or set of goal". Kepemimpinan adalah kemampuan untuk mempengaruhi suatu kelompok kearah pencapaian visi atau serangkaian tujuan. Selanjutnya akan dibahas mengenai kepemimpinan transformasional. Menurut McShane \& Von Glinow (2008:414) "transformational leaders are agents of change, they create, communicate, and model a shared vision for the team or organization, inspiring followers to strive for that vision". Menurut teori ini para pemimpin transformasional adalah pelaksana perubahan, mengkomukasikan visi dan menjadi teladan dalam melaksanakan visi organisasi, serta memberikan inspirasi bagi para karyawan untuk berjuang sekuat tenaga demi terlaksananya visi tersebut.

Menurut Slocum dan Hellriegel (2011:329-330) "transformational leadership involves anticipating future trends, inspiring followers to understand and embrace a new vision of possibilities. The key interrelated components of transformational leadership include individualized consideration, intellectual stimulation, inspirational motivation, and idealized influence". Kepemimpinan transformasional berkaitan dengan antisipasi terhadap kecenderungan-kecenderungan yang terjadi pada masa mendatang, memberi inspirasi kepada para karyawan untuk mengetahui dan memahami kemungkinan adanya visi baru. Komponen utama dari kepemimpinan transformasional adalah (1) individualized consideration-memperhatikan individu, (2) intellectual stimulation-stimulasi daya intelektual, (3) inspirational motivation-mendorong inspirasi, (4) idealized influenceberpengaruh secara ideal. Selanjutnya Robbins menyatakan, "transformational leaders is leaders who inspire followers to transcend their own self-interests and who are capable of having a profound and extraordinary effect on followers". Kepemimpinan transformasional merupakan pemimpin yang menginspirasi para pengikut untuk melampaui kepentingan pribadi mereka dan yang mampu membawa dampak mendalam dan luar biasa kepada para pengikutnya.

Berdasarkan deskripsi konsep di atas dapat disintesiskan kepemimpinan transformasional adalah perilaku seseorang dalam mengarahkan, mengembangkan potensi, dan menggerakkan potensi, serta menggerakkan bawahan untuk mencapai tujuan organisasi dengan indikator: (1) menginspirasi perubahan, (2) menjadi peran model (3) stimulasi intelektual (4) perhatian pada bawahan.

\section{Kepuasan Kerja}

Setiap orang dalam bekerja umumnya menginginkan kepuasan dari tempatnya bekerja yang disebut dengan istilah kepuasan kerja. Tingkat kepuasan seseorang sangat tergantung pada tingkat harapan dan tingkat pencapaian harapan. Pada dasarnya kepuasan kerja merupakan hal yang bersifat individu karena setiap individu memiliki tingkat kepuasan yang berbeda sesuai dengan nilai-nilai yang dipahaminya. Sumber kepuasan ditentukan oleh beberapa hal seperti pandangan seseorang terhadap sesuatu, tingkat pemenuhan, dan tingkat keinginan seseorang terhadap segala sesuatu di sekelilingnya. Menurut Fred Luthans (2011:141) "job satisfaction is a result of employees' perception of how well their job provides those things that are viewed as important". Kepuasan 
kerja adalah hasil persepsi karyawan dari seberapa baik pekerjaan mereka memberikan hal-hal yang dipandang sama pentingnya. Selanjutnya Luthans juga mengungkapkan ada lima dimensi yang mempengaruhi kepuasan kerja, yaitu: "Five job dimensions have been identified to represent the most important characteristics of a job about which employees have affective responses. These are: (1) the work itself, (2) pay, (3) promotion opportunities, (4) supervision, and (5) cowokers". Terdapat lima dimensi pekerjaan yang diidentifikasi untuk mewakili karakteristik yang paling penting dari pekerjaan yang memiliki respon afektif karyawan, yaitu: (1) pekerjaan itu sendiri, (2) gaji, (3) kesempataan promosi, (4) supervisi, dan (5) rekan kerja.

Menurut Colquitt, Lepine dan Wesson (2013:98) menyatakan "job satisfaction is defined as a pleasurable emotional state resulting from the appraisal of one's job or job experiences. In other words, it represents how you feel about your job and what you think about your job. Employees with high job satisfaction experience positive feelings when they think about their duties or take part in task activities. Employees with low jo satisfaction experience negative feelings when they think about their duties or take part in their task activities". Kepuasan kerja didefinisikan sebagai kondisi emosional yang menyenangkan hasil penilaian dari suatu pekerjaan atau pengalaman pekerjaan seseorang. Hal itu menghadirkan perasaan tentang pekerjaan dan apa yang dipikirkan tentang pekerjaan. Pekerja dengan kepuasan tinggi mengalami hal-hal positif pada saat mereka memikirkan tugas-tugas mereka atau mengambil bagian dalam aktivitas tugas tersebut. Pekerja dengan kepuasan kerja rendah mengalami hal-hal negatif pada saat mereka memikirkan tugas-tugas mereka atau mengambil bagian dalam aktivitas tugas mereka. Tinggi rendahnya kepuasan kerja seseorang tergantung pada faktor-faktor yang mempengaruhinya. Menurut Colquitt, Lepine, dan Wesson (2013:98) terdapat 8 faktor yang mempengaruhi kepuasan kerja, yaitu: (1) Pay (hight salary, secure salary), (2) Promotion (frequent promotions, promotion based on ability), (3) Supervision, (4) Cowoker (enjoyable cowokers, responsible cowokers), (5) Work it self, (6) Altruism (helping others, moral causes), (7) Status (prestige, power over others), (8) environment (comfort, safety). Pendapat ini menunjukkan bahwa: gaji, kenaikan jabatan, supervisi, kerja sama kelompok, pekerjaan itu sendiri, status kerja, sikap mementingkan kerja sama, dan lingkungan kerja merupakan faktor yang dapat mempengaruhi kepuasan kerja para pegawai. Selanjutnya menurut Schermerhorn dan Hunt (2010:72) "job satisfaction, an attitude reflecting a person's positive and negative feelings toward a job, coworkers, and the work environment". Kepuasan kerja merupakan sikap yang mencerminkan perasaan positif dan negatif seseorang terhadap pekerjaan, rekan kerja dan lingkungan kerja.

Berdasarkan deskripsi konsep di atas, dapat disintesiskan kepuasan kerja adalah perasaan senang dan tidak senang seseorang terhadap pekerjaannya yang merupakan hasil penilaian terhadap aspek pekerjaannya, dengan indikator: (1) perasaan terhadap upah, (2) perasaan terhadap penghargaan, (3) perasaan terhadap supervisi, (4) perasaan terhadap hubungan rekan kerja, dan (5) perasaan terhadap hubungan atasan-bawahan, dan (6) perasaan terhadap kondisi kerja.

\section{METODE PENELITIAN}

Penelitian ini dilaksanakan di Sekretariat Badan Pengembangan Sumber Daya Manusia Perhubungan. Pendekatan penelitian dilakukan secara kuantitatif, dengan metode survey, diukur menggunakan instrumen kuisioner. Analisis data menggunakan statistik parametris dengan path analysis. Penelitian ini dilaksanakan kepada pegawai Sekretariat Badan Pengembangan Sumber Daya Manusia Perhubungan yang berjumlah 
114 pegawai dengan jumlah sampel 89 pegawai. Data dikumpulkan dengan menggunakan instrumen berupa kuisioner yang telah diuji validitas dan reliabilitasnya.

\section{HASIL PENELITIAN DAN PEMBAHASAN}

\section{Pengaruh Kepemimpinan Transformasional terhadap Motivasi Berprestasi}

Dari hasil pengujian hipotesis pertama dapat disimpulkan bahwa terdapat pengaruh langsung positif kepemimpinan transformasional terhadap motivasi berprestasi dengan nilai koefisien korelasi sebesar 0,446 dan nilai koefisien jalur sebesar 0,333 . Ini memberikan makna kepemimpinan transformasional berpengaruh langsung terhadap motivasi berprestasi.

Hasil penelitian ini senada dengan beberapa pendapat para ahli diantaranya Miriam Erez, Uwe Kleinbeck, dan Henk Thierry (2001:283) "at a more elemental level, transformational leadership behaviors that are consistent with each other will increase motivation by activating the same or complementary needs in employees or by involving the same or complementary aspect of their self-concepts". Pada tingkat yang lebih mendasar, perilakuperilaku kepemimpinan transformasional secara konsisten akan meningkatkan motivasi dengan cara memenuhi setiap kebutuhan dari karyawan atau dengan melibatkan aspek yang sama pada konsep diri mereka. Dengan kata lain seorang pemimpin transformasional akan lebih peka terhadap kebutuhan-kebutuhan pegawainya sehingga hal ini dapat meningkatkan motivasi dari pegawai tersebut untuk meraih prestasi.

Selanjutnya Menurut Gary Yukl mengungkapkan bahwa "transformational leadership increases follower motivation and performance more than transactional leadership, but effective leaders use a combination of both types of leadership". Kepemimpinan transformasional lebih meningkatkan motivasi dan kinerja pengikut daripada kepemimpinan transaksional, tetapi pemimpin yang efektif menggunakan kombinasi dari kedua jenis kepemimpinan tersebut.

Berdasarkan uraian di atas, maka kepemimpinan transformasional berpengaruh langsung positif terhadap motivasi berprestasi. Dengan ketepatan kepemimpinan tranformasional terhadap pegawai, maka dapat meningkatkan motivasi berprestasi pegawai dalam melakukan pekerjaannya.

\section{Pengaruh Kepuasan Kerja terhadap Motivasi Berprestasi}

Dari hasil pengujian hipotesis kedua dapat disimpukan bahwa terdapat pengaruh langsung positif kepuasan kerja terhadap motivasi berprestasi dengan nilai koefisien korelasi sebesar 0,459 dan nilai koefisien jalur sebesar 0,352. Ini memberikan makna kepuasan kerja berpengaruh langsung positif terhadap motivasi berprestasi.

Hasil penelitian ini senada dengan beberapa pendapat ahli antara lain, John R. Schermerhom, et al (2010:115) mengungkapkan "when motivator factors are minimal, low job satisfaction decreases motivation and performance; when motivator factors are substantial, high job satisfaction raises motivation and performance". Ketika faktor motivator minim, kepuasan kerja rendah serta menurunnya motivasi dan kinerja; ketika faktor- faktor motivator kuat, kepuasan kerja yang tinggi meningkatkan motivasi dan kinerja. Dari penjelasan dapat diartikan bahwa apabila dalam suatu perusahaan atau organisasi keberadaan motivator atau faktor-faktor yang mendorong motivasi minim maka hal yang terjadi adalah kepuasan kerja rendah serta menurunnya motivasi dan kinerja. Namun sebaliknya apabila faktor-faktor yang mendorong motivasi kuat, kepuasan kerja tinggi maka hal ini dapat meningkatkan motivasi dan kinerja dari karyawan. 
Selanjutnya menurut Steven McShane dan Mary Von Glinow mengungkapkan, “.... job satisfaction influences employee motivation but doesn't affect performance in jobs where employees have little control over their job output (such as assembly-line work)". Kepuasan kerja mempengaruhi motivasi karyawan tapi tidak mempengaruhi kinerja dalam pekerjaan di mana para karyawan memiliki sedikit kontrol atas hasil pekerjaan mereka (seperti kerja perakitan). Hal diatas dapat dimaknai bahwa kepuasan kerja dari seorang karyawan dapat mempengaruhi motivasi karyawan, seorang karyawan yang memiliki kepuasan kerja yang tinggi maka ia akan memiliki motivasi yang tinggi pula khususnya motivasi berprestasi. Berdasarkan uraian di atas, maka kepuasan kerja berpengaruh langsung positif terhadap motivasi berprestasi.

\section{Pengaruh Kepemimpinan Transformasional terhadap Kepuasan Kerja}

Dari hasil pengujian hipotesis ketiga dapat disimpulkan bahwa terdapat pengaruh langsung positif kepemimpinan transformasional terhadap kepuasan kerja dengan nilai koefisien korelasi sebesar 0,321 dan nilai koefisien jalur sebesar 0,321. Ini memberikan makna kepemimpinan transformasional berpengaruh langsung positif terhadap kepuasan kerja.

Hasil penelitian ini senada dengan beberapa pendapat ahli diantaranya Steven McShane dan Mary Von Glinow (2008:418) yang mengungkapkan “.... subordinates are more satisfied and have higher affective organizational commitment under transformational leaders". Bawahan lebih puas dan memiliki komitmen organisasi afektif yang lebih tinggi di bawah pemimpin-pemimpin transformasional. Hal ini menunjukkan bahwa kepemimpinan transformasional dapat meningkatkan kepuasan kerja dan komitmen organisasi seorang karyawan. Selanjutnya menurut Gomes-Mejia, Balkin, Cardy (2008:520) menyatakan "overall, transformational leadership is more likely then transactional leadership to reduce turnover rates, increase productivity, and improve employee satisfaction". Secara keseluruhan, kepemimpinan transformasional lebih mungkin daripada kepemimpinan transaksional untuk mengurangi tingkat turnover, meningkatkan produktivitas, dan meningkatkan kepuasan karyawan. Jika pegawai menganggap bahwa kepemimpinan transformasional seorang pemimpin dalam organisasi sesuai maka akan makin tinggi pula kepuasan kerja yang pegawai rasakan. Berdasarkan uraian di atas, maka kepemimpinan transformasional berpengaruh langsung positif terhadap kepuasan kerja.

\section{PENUTUP}

Kesimpulan: Berdasarkan hasil dan analisis data, maka dapat diambil kesimpulan: (1) Kepemimpinan transformasional berpengaruh langsung positif terhadap motivasi berprestasi. Artinya ketepatan dalam kepemimpinan transformasional mengakibatkan peningkatan motivasi berprestasi pegawai Sekretariat Badan Pengembangan Sumber Daya Manusia Perhubungan; (2) Kepuasan kerja berpengaruh langsung positif terhadap motivasi berprestasi. Artinya peningkatan kepuasan kerja mengakibatkan peningkatan motivasi berprestasi pegawai Sekretariat Badan Pengembangan Sumber Daya Manusia Perhubungan; dan (3) Kepemimpinan transformasional berpengaruh langsung positif terhadap kepuasan kerja. Artinya ketepatan dalam kepemimpinan transformasional mengakibatkan peningkatan kepuasan kerja pegawai Sekretariat Badan Pengembangan Sumber Daya Manusia Perhubungan.

Saran: Berdasarkan kesimpulan di atas, maka saran yang perlu ditindak lanjuti antara lain: 
1. Bagi pimpinan dan pejabat di lingkungan Sekretariat Badan Pengembangan Sumber Daya Manusia Perhubungan agar dapat menjalin hubungan para pegawai sehingga meningkatkan motivasi berprestasi pegawai dengan memberikan perhatian pada pegawai menjadikan sebagai model yang dapat diteladani oleh pegawainya.

2. Bagi para rekan-rekan pegawai Sekretariat Badan Pengembangan Sumber Daya Manusia Perhubungan dapat meningkatkan motivasi berprestasi dengan selalu berusaha untuk menjadi lebih unggul, bertanggungjawab sehingga memperoleh prestasi sebaik-baiknya dalam melaksanakan setiap pekerjaannya. 


\section{DAFTAR RUJUKAN}

Colquitt, Jason A., Lepine, Jeffry A. dan Wesson, Michael J. (2013). Organizational Behavior 4th Ed. New York: McGraw-Hill.

Erez, Miriam., Kleinbeck, Uwe dan Thierry, Henk. (2001). Work Motivation in the Context of a globalizing Economy. New Jersey: Lawrence Erlbaum Associates Inc.

Gomez-Meija, Luis R., Balkin, David B., dan Cardy, Robert L. (2008). Management: People Performance Change 3rd Ed. New York: McGraw-Hill, 2008.

Luthans, Fred. (2011). Organizational Behavior 12th Ed. New York: McGraw-Hill.

Luthans, Fred dan Doh, Jonathan P. (2012). International Management 8th Ed. New York: McGraw-Hill.

McShane, Steven L dan Glinow, Mary Ann Von. (2008). Organizational Behavior 4th Ed. New York: McGraw-Hill.

Robbins, Stephen P dan Judge, Timothy A. (2013). Organizational Behavior 15th Ed. New Jersey: Pearson.

Schermerhorn, John R., et.al. (2010) Organizational Behavior 11th Ed. International Student Version, 2010.

Slocum, John W dan Hellriegel, Don. (2011). Organizational Behavior 13th Ed. Mason: South Western.

Yukl, Gary. (2010). Leadership in Organizations 7th Ed. New Jersey: Prentice Hall. 